\title{
Inter-Federal-Regional Conflict Resolution Mechanisms in Ethiopian Federacy: A Comparative Appraisal on the Legal and Institutional Frameworks
}

\author{
Habtamu Birhanu*, Zelalem Kebu \\ College of Law and Governance Studies, Dilla University, Dilla, Ethiopia \\ Email: ^habtbranu6@gmail.com, zolabekele@gmail.com
}

How to cite this paper: Birhanu, H. and Kebu, Z. (2019). Inter-Federal-Regional Conflict Resolution Mechanisms in Ethiopian Federacy: A Comparative Appraisal on the Legal and Institutional Frameworks. Beijing Law Review, 10, 1374-1393. https://doi.org/10.4236/blr.2019.105074

Received: October 9, 2019

Accepted: December 20, 2019

Published: December 23, 2019

Copyright $\odot 2019$ by author(s) and Scientific Research Publishing Inc. This work is licensed under the Creative Commons Attribution International License (CC BY 4.0).

http://creativecommons.org/licenses/by/4.0/

(c) (i) Open Access

\begin{abstract}
The FDRE Constitution, formally, establishes federal form of state structure on the basis of ethno-territorial-linguistic criteria according to which nine regional states have been formed. Federalism, in turn, institutionalizes the division of power between federal and regional states that may render inter-governmental disputes in their interactions inevitably. The possibility of inter-governmental disputes, thus, necessitates the institutionalized intergovernmental dispute resolution mechanisms between these two tiers of governments. Being informed of federal characteristics, the Constitution extends the legislative, executive and judicial powers both for federal and regional governments. In equal footing, the Constitution further provides that both federal and regional states shall respect the power of one another. And the federal government may, whenever necessary, delegate to the states the power and functions granted to it by article 51 of the Constitution; leaving residual power (power given neither exclusively to either of them or concurrently to both of them) under the exclusive competence of the regional states. Though both federal and regional governments are constitutionally vested with different power and supposed to act distinctively and independently, overlapping of power between the two levels of governments is self-evident eventually. Be what it may, the FDRE Constitution has no specific provision dealing with intergovernmental relations in general and federal-regional dispute resolution mechanisms in particular though it is of crucial importance to subsist prime values of federalism and overcome the possibilities of intergovernmental disputes pragmatically. The objective of this article is, thus, to examine legal and institutional frameworks for federal-regional intergovernmental dispute resolution mechanisms in Ethiopian federacy and draw the
\end{abstract}


conclusion that the necessity of having the institutionalized federal-regional intergovernmental dispute resolution mechanisms. In doing so, the article has employed comparative means and analysis of the related legal documents. To this end, the experiences of Kenyan, Nigerian and South African have been consulted so as they are found with the best lessons and practices in comparison. Finally, the article found out that there has been a need to have Federal-Regional Dispute Settlement Mechanism beyond board in Ethiopia.

\section{Keywords}

Ethiopian Federalism, House of Federation, Intergovernmental Relations, Intergovernmental Dispute Resolution Mechanisms, Ministry of Peace

\section{Introduction}

The Constitution of Federal Democratic Republic of Ethiopia (herein after referred as "The Constitution") establishes federal form of state structure on the basis of ethno-territorial and linguistic line. Accordingly, nine regional states have been formed constitutionally. ${ }^{1}$ It further provides that both federal and regional states shall respect the power of one another. And the federal government may, when necessary, delegate to the states the powers and functions granted to it by art 51 of the Constitution, ${ }^{2}$ leaving residual power to regional states apparently. On top of this, the principle of "mutual respect" between federal and state governments and "rule of non-interference" in one another affair are recognized in the Constitution (Regassa, 2004; Wondirad, 2014). The overall division of power between federal and regional governments, at least theoretically, reveals the dual nature of Ethiopian federal state structure under which both federal and regional governments have distinctive and independent legislative, executive and judiciary. ${ }^{3}$ Under this framework, both federal and regional states are autonomous with their respective power and act independently in discharging their constitutional duties. Their distinctiveness, indeed, does not mean none interconnection for good or switching against one another. In other words, there are instances in which both federal and regional governments are expected to act together including with possible delegation either horizontally or vertically. Being facts on the ground, the Constitution has no specific provision dealing with federal-regional and inter-regional governmental relations though it is of vital importance to maintain core values of federalism by overcoming the possibilities of overlapping of jurisdictions and intergovernmental disputes. To be specific, despite the major concurrent constitutional responsibility of the federal and regional states, the Constitution contains no explicit reference to intergovernmental cooperation and it does not expressly state the obligations of the respective ${ }^{1}$ The Constitution of Federal Democratic Republic of Ethiopia, Proclamation No. 1/1995, $1^{\text {st }}$ year, Addis Ababa $21^{\text {st }}$ August 1995, art.1, 47, 47, and Art 50 (1).

${ }^{2}$ Ibid, art 50 (9).

${ }^{3}$ Ibid, art 50 (2). 
levels of government in preserving the constitutional order (Afesha, 2015). There are, thus, both the legislative and institutional gaps in intergovernmental relations, which should have been established with an explicit aim of facilitating the cooperation. (Ibid) Due to this fact, there are weak and informal means of intergovernmental relation mainly through having mere representatives in the HoF to deal with matters of common concern, interrelation based on some selected sectorial regimes and partisan system between federal-regional governments.

The worst scenario in this regard is that incorporating specific provision to deal with inter-regional dispute or misunderstanding resolution mechanism in black and white; ${ }^{4}$ the Constitution contains no single provision to handle federal-regional dispute resolution mechanisms. To put forward in plain tabulation, federal-regional conflict resolution mechanism is missing under the Constitution, at least by setting aside its pragmatic relevancy to make federal system more sustainable and predictable towards realizing the consecrated promise of the Constitution. Thus, the article is meant to examine the legal and institutional framework for federal-regional intergovernmental relation and dispute resolution mechanisms in Ethiopian federalism thoroughly. In doing so, it tries to look into the Constitutions of three African countries namely South Africa, Nigeria and Kenya for the comparative appraisal. These countries are purposely selected for two reasons. Firstly, the first two countries share some common features of federalism with Ethiopia except the last one for it is unitary devolutionary form of government. Secondly, three of them especially, South Africa and Kenya have well developed legal and institutional framework to resolve intergovernmental disputes.

The article firstly presents the conceptual framework of intergovernmental relations. It goes on by highlighting Federal-Regional Intergovernmental Disputes in the federation. Then it will discuss the intergovernmental dispute resolution mechanisms in selected countries. Before making a comparative appraisal on Federal-regional intergovernmental dispute resolution mechanisms in Ethiopian federacy, the article has made an overview of intergovernmental relation in Ethiopia. Finally, it makes thorough discussion on Federal-regional intergovernmental dispute resolution mechanisms in Ethiopian federacy in comparative perspective. Finally, the paper comes to an end with conclusion. It is important to note that it is a study of the normative framework for inter-federal-regional intergovernmental dispute resolution mechanism in Ethiopian federacy. The study is limited to the analysis of the constitutional, and other relevant legal provisions as the case may be.

${ }^{4}$ Ibid, as per art 48 of the FDRE Constitution, all state dispute shall be settled by the agreement concerned states and when they failed to reach agreement, the House of Federation shall decide such disputes with two years. Moreover, as per art 62 (6) of FDRE Constitution HoF has the mandate to strive to find solution that may occur among states. Thus, as per art $32(1,2)$ of Proc. No. 251/2001 "The House shall request the parties to resolve their misunderstandings by peaceful means and discussion where their misunderstanding is other than border disputes and it shall also attempt to abridge their difference. If the concerned parties could not resolve their misunderstandings through discussion, the House shall strive to find a solution in any mechanism possible.” 


\section{A Basic Circle of Intergovernmental Relation}

It is a daunting task to define the term intergovernmental relation in a very conclusive and water tight statement. But as the working definition, for example, Van and Toit have referred it as the "mutual relations and interactions between government institutions at horizontal and vertical levels." (Van der Waldt \& du Toit, 1997; Bello, 2014). It is further described as a plethora of formal and informal relationships and transactions that develop among levels of government within a nation-state (Bello, 2014). It is to be recalled that it is a forum of bargaining with the federal government on matters of common interest and if conducted based on some sense of partnership between the two governments then after towards attainment of common goals through cooperation (Assefa, 2009). Accordingly, intergovernmental relations are cross-cutting in nature by encompassing all their manifestations and relations between various units of government (Opeskin, 1999) including entire complex and interdependent relational spheres of government and the co-ordination of public policies among different levels (Mitullah, 2012). To be specific, it refers to the relation between and within levels of government in the attainment of common goal through cooperation and interaction having the legal and institutional mechanisms therewith through which bilateral and multilateral interactions within and between the various levels of government occur in furtherance of governmental policies and function (Opeskin, 1999). Thus, it can be defined as the "glue" that holds them together (Bello, 2014).

Intergovernmental relation has vertical and horizontal dimensions. Succinctly, the vertical dimension of IGR is an interaction between/among the federal government, sub-national constituent units and local governments. The horizontal dimension is, on the other hand, mainly practiced between/among sub-national/ constituent units themselves.

The aim of intergovernmental relations is, primarily, to enable governmental activities through synergy, effectiveness and efficacious in delivering services, sustainable democratic process and strengthen delivery capacity across all spheres of government for the common good (Isioma, 2010). It is also important in installing the culture of negotiation between the federal government and the states, checking the trend of centralization and thereby enhancing the bargaining power of the states (Assefa, 2009). It also focuses on how different orders of government in federal political systems communicate and collaborate with each other. Accordingly, it facilitates negotiation, non-hierarchical exchange of information and cooperation between the institutions of the two levels of governments (Afesha, 2015). More importantly, intergovernmental relation is an important principle in realizing synergy among different levels in the governance system of a country and within specific levels for stability of entire government (Mitullah, 2012).

Moreover, the goals of intergovernmental relations are also to promote peace and harmony, minimize (avoid) inter-jurisdictional conflicts among federal and 
states orders of government, improve greater natural economic integration and enhance effective and efficient utilization of available human and material resources (Kenna, 2014). Institutionalizing intergovernmental relations could, thus, further facilitate resolving potential central vis state conflict (Assefa, 2009).

\section{Federal-Regional Intergovernmental Disputes}

Federalism institutionalizes the division of power that can create the circumstances to render inter-governmental relations, which could produce disputes inevitably (Adem, 2013). In other word, dispute between different level of state and federal units is expected in any federal system (Harun, 2016). The existence of layers of government and formal division of power elevates the likelihood of jurisdictional disputes between different levels of the government. (Hogg Peter W., 1985 cited in Adem, 2013) This can be triggered by a wide range of issues such as question over land, boundaries, natural resources, resource distribution and the like that dispute resolution mechanisms are essential and of practical necessity (Harun, 2016). It is, thus, necessary that federal Constitution should establish mechanisms for the peaceful umpiring of such disputes (Adem, 2013). Specifically, institutionalized dispute resolution mechanisms are necessary for the harmonious existence and continuity of a federal system. (Ibid) It is envisaged as a matter of fact that the inevitability of conflicts between different levels of government structures that demand the proper settlement forums (Bekalu, 2015).

Having established the inevitability of dispute between and among different spheres of government in federal state owing to various factors, equally important thing to be considered is a mechanism that should be put in place to resolve federal-regional disputes. The institutional quest that should be confined the power of disposing federal-regional dispute is the point of arduous controversy among scholars. Because, owing to their political and historical context, consequently, different regimes adopted a mechanism they consider fit their context so as divergence has been normal whereas convergence has made an exception. This being fact on the ground, an account that institutionalized to flourish forum for umpiring federal-regional dispute is the matter of necessity for the harmonious interaction between and among various layers of government. Saving the ebb and flow in this regard, for the comparative purpose, the experiences of Nigeria, South Africa and Kenya have been discussed due to their predominant practice and demonstration if there be any betterment for Ethiopia to derive therefrom accordingly.

\section{Intergovernmental Dispute Resolution in Nigeria, South Africa and Kenya}

\subsection{The Nigerian Experience}

Nigeria is the oldest and most established federated state in Africa (Adem, 2013) 
and is a country of extraordinary diversity and complexities in its Constitution (Akai, 2017). These complexities are reflection of the avalanche of ethno-cultural and religious groups co-habiting in the country and intricacies of interaction among them (ibid), the structure of its federalism can be traced far back to 1914 when the northern and southern protectorates were amalgamated though under unitary administration. (Ibid) It was during the time that the nation was observed to have comprised of many cultural groups, which were in the colonial processes and later metamorphosed into specie in the genus of multi-ethnic political and social communities' so-called federalism (Tella, Doho, \& Bapeto, 2014).

Formally, however, the federation composed of thirty-six constituent states and a Federal Capital, Abuja, have been formed since 1996. The federal arrangement in Nigeria under the Constitution is premised on a distinctive division of power between the central (federal) and the constituent units (Amah, 2017). This involves the sharing of power between the federal and state governments to foster easy administrations, cooperation and promote the principle of separation of power. (Ibid) It appears that the basic goal of federalism in Nigeria is to promote the unity of the country, saving therein accommodative room for the political autonomy of different sections of Nigerian (Amah, 2016).

The 1999 Constitution anticipates disputes between different levels of government and establishes institutional structures for the peaceful resolution of such disputes (Adem, 2013). It gives the power to settle disputes between the federal government and states as well as amongst the states, horizontally, to the Supreme Court of Nigeria. ${ }^{5}$ The fact that both the federal and state governments are involved in appointment of members of the Supreme Court, which could enhance the neutrality and legitimacy of the Court and its decisions in adjudicating and assuming jurisdiction over federal-state dispute. (Ibid) Therefore, the balance can be said potent enough in out casting systematic judicial bias either towards the federal or the states. (Ibid)

\subsection{The South African Trends}

In South Africa, the most important achievement of the new constitutional system is the replacement of the notion parliamentary sovereignty which was a paradigmatic feature of the apartheid regime, with the idea of "Constitutional Democracy" under the custodianship of the South African Constitutional Court. (Ibid) In striking contrast to the unitary and highly centralized apartheid government, aftermath of apartheid, South Africa has highly been decentralized. (Ibid) Unlike the 1999 Constitution of Nigeria, however, the 1996 of the South Africa's Constitution does not specifically designate South Africa as a federated state. It rather establishes Democratic Republic form of government that has ${ }^{5}$ Section 232 (1) of the Supreme Court shall, to the exclusion of any other court, have original jurisdiction in any dispute between the Federation and a state or between states if and in so far as that dispute involves any question (whether of law or fact) on which the existence or extent of a legal right depends. 
founded on the principles elucidated under section $1 .{ }^{6}$ Yet, it clearly embodies the principles and basic features of federalism in which provinces have powers that the central government cannot infringe and vice-versa except through a constitutional amendment. In this regard, Chapter 3 of the Constitution of the Republic of South Africa (Section 40) outlines the structure of government into three distinctive, interdependent and interrelated bodies or spheres with their own areas of operation. They consist of national, provincial and local governments. Moreover, the provinces have permanent representation in the central government through the Council of Provinces. These features clearly qualify South Africa as a federated state (Adem, 2013).

The commitment of South African government to cooperative government and the promotion of intergovernmental relations are emphasized by section 41 . The Constitution under section 41(1) states that "government is constituted as national, provincial and local spheres of government which are distinctive, interdependent and interrelated." (emphasis added) (Layman, 2003). As explicated under this article, national, provincial and local governments are distinctive, interdependent and interrelated.

Distinctiveness of the National, Provinces and local spheres refers to the autonomous nature of each of them so that all of them shall, inter alia, perform their respective functions and powers, saving therein respecting the functional and institutional integrity of one another. In this respect, section 41 (1) (e) of the Constitution dictates that they should respect for the constitutional status of institutions, power and functions of government at every level of governance. Section 41 (f) adds that spheres must "not assume any power or function except that those conferred on them in express stipulation of the Constitution" and "cooperate with one another in mutual trust and good faith." This principle, shortly, conveys that each sphere of government must exercise their respective power and functions in a manner that it does not extend to encroach in the geographical, functional or institutional integrity of government in another sphere. ${ }^{7}$

On the other hand, their interdependence, as contemplated in the Constitution, does not exclude the coordination among National, Provinces and Local levels. The government at each level shall co-operate in executing their functions and exercising their power respectively. In other words, no sphere is expected to operate in isolation. Their interrelatedness implies that spheres are crucial parts that collectively form the government of the country through a holistic system of government that could evolve towards solid and unified governance. (Malan L., 2005) To this end, section $41(\mathrm{a}-\mathrm{c})$ submits that spheres must "preserve peace, national unity and indivisibility of the Republic" through the provision of "effective, transparent, accountable and coherent government for the Republic as a ${ }^{6}$ Under section 1 of the 1996 Constitution of South Africa, the Republic of South Africa is one, sovereign, Democratic state founded on the values of human dignity, achievement of equality and human rights and freedoms; non-racialism and sexism; supremacy of the Constitution and rule of law; universal adult suffrage, a national common voters roll, regular election, and multi-party system democratic government, to ensure accountability, responsiveness and openness.

${ }^{7}$ Constitution of South African, 1996, section, 41 (1(g)). 
whole." Anticipating the inevitability of dispute that may occur between different layers of government, the Constitution under section 41 (2 (b)) stipulates, Act of Parliament must establish or provide for structures and institutions to promote and facilitate intergovernmental relations; and appropriate mechanisms and procedures to facilitate settlement of intergovernmental disputes. For apparent reason of preserving unity and the spirit of togetherness, it goes without saying that an organ of the state involved in an intergovernmental dispute must, make every reasonable effort to settle dispute by means of mechanisms and procedures provided for that purpose, exhaust all other remedies before approaching the court to resolve the dispute. ${ }^{8}$

The national government enacted the Inter-governmental Relations Framework Act of 2005 (hereafter referred as "the Act") with the view of establishing a general legislative framework applicable to all spheres and sectors of government to ensure the conduct of intergovernmental relations in spirit of the Constitution. ${ }^{9}$ The Act provides for both Alternative Dispute Resolution (ADR) and formal Dispute Resolution mechanisms in black and white. Section 41 (2) of the Act notes that "before resorting to the formal dispute resolution mechanism; the government organ in question must make every reasonable effort to settle the dispute in good faith, including through the initiation of direct negotiations with one other or negotiations through an intermediary modestly." By the same token, section 40 (1) of the Act notes that all organs of state must make every reasonable effort to avoid intergovernmental disputes when exercising their statutory powers or performing their statutory functions and to settle intergovernmental disputes without resorting to judicial proceedings'. It is only if this fails that a party to a dispute may formally declare a dispute by notifying the other party of such declaration in writing. ${ }^{10}$ Once a formal intergovernmental dispute has been declared, the parties to the dispute must promptly convene a meeting between themselves or their representatives to determine the nature of the dispute precisely and any material issues, which are not in dispute. The parties are also imposed to identify and consult any mechanisms or procedures amicably, other than judicial proceedings. Besides, they should not set aside any mechanism or procedure provided in legislation or any agreement between them according to the pertinent rule of sub-section (2). Where a mechanism or procedure is specifically provided in other legislation or in an agreement between the parties, the parties must make every reasonable effort to settle the dispute in terms of such mechanism or procedure. ${ }^{11}$

Concerning judicial proceeding, section 45 (1) provided that 'No government or organ of state may institute judicial proceedings in order to settle an intergovernmental dispute unless the dispute has been declared a formal intergovernmental dispute according to section 41 and all efforts to settle the dispute here${ }^{8}$ Constitution of South African, 1996, section 41 (3).

${ }^{9}$ Republic of South Africa's Intergovernmental Relations Framework Act, No. 13/2005.

${ }^{10}$ Ibid, Section 41 (1).

${ }^{11}$ Republic of South Africa's Intergovernmental Relations Framework Act, No. 13/2005, Section 41 (1). 
with were unsuccessful. Only if these fail that a party to a dispute may formally proceed to judicial proceeding by referring the matter to the judicial organ that is constitutionally vested with the power to referee in entertaining intergovernmental dispute. Thus, any intergovernmental dispute between the national government and provinces is subject to the first instance and exclusive jurisdiction of the African Constitutional Court. ${ }^{12}$ Bear in mind that all negotiations in terms of section 41, discussions in terms of section 42 and reports in terms of section 43 are privileged and may not be used in any judicial proceedings as evidence by or against any of the parties to an intergovernmental dispute.

\subsection{Kenyan Experience}

In fact, unlike Nigeria and South Africa, Kenya is not attributable to federated state structure in strict sense of the term. This being so, why Kenya is chosen is for two interrelated reasons apparently. The first reason is to indicate institutionalized intergovernmental relation in general and the recognition given for an intergovernmental dispute resolution mechanism in unitary system of government in the way demonstrating such settlement mechanism is not only meant for the federated states. Thus, it is possible for federation like Ethiopia to take lesson even from unitary state structure. The second reason is that unlike Ethiopia, Kenya has well developed legal and institutional framework for intergovernmental dispute resolution mechanism. So, there would be a possibility to derive its best experience for adoption.

Kenya exercises a democratic republic form of government with a multi-party system founded on national values and principle of governance as contemplated under section $10^{13}$ of the 2010 Kenyan Constitution. The 2010 of Kenyan Constitution (herein after referred as "The Constitution of Kenya") introduced Republican kind of governance both at the National and County level. ${ }^{14}$ Both national and county are distinct and interdependent. Distinctiveness of the National and County's governments in Kenya refers to the autonomous nature of both national and county. Each of them are mandated to exercise its functions and power in a manner that respects the over wellbeing of functional and institutional integrity of government at all levels indifferently. Their interdependence, on the other hand, as set forth in the Constitution, emphasizes the strict relationship between national and County. Thus, national government and different governments at the county level shall co-operate in the performance of functions and exercise of power. To this end, they may set up joint committees and joint authorities. These principles are explicated under section 6 (2) and 189 (1) of the Constitution of Kenya. On the basis of key constitutional requirements

${ }^{12}$ The South African Constitution of 1996, Section 167 (4).

${ }^{13}$ The national values and principles of governance include patriotism, national unity, sharing and devolution of power, the rule of law, democracy and participation of the people; human dignity, equity, social justice, inclusiveness, equality, human rights, non-discrimination and protection of the marginalized, good governance, integrity, transparency and accountability; and sustainable development.

${ }^{14}$ Constitution of Kenya, 2010: Section 4(1), 6(1). 
of distinctiveness and interdependence, both national and Counties are supposed to conduct their inter-governmental relations on the basis of consultation and cooperation. In discharging their constitutionally defined roles or functions, both level of governments must observe and be guided by those two key principles of intergovernmental relations, i.e. on the basis of consultation and cooperation. ${ }^{15}$

As far as the potential disputes between different layer of governments are concerned, the Constitution under section 189 (3) stipulates, "the governments shall make every reasonable effort to settle the dispute through whatever plausible mechanisms beside means of procedures provided under national legislation." Under its sub-section 4, it clearly provides that national legislation shall provide procedures for settling intergovernmental disputes by alternative dispute resolution mechanisms, including negotiation, mediation and arbitration. To put these Constitutional provisions operational, the national government has enacted the Intergovernmental Relations Act in 2012 (herein after referred as "the IGR Act") for the advancement of intergovernmental relations in general and settling dispute between National and County in particular. ${ }^{16}$

The Act has established institutional framework for the resolution of intergovernmental disputes as provided in section 6 and 189 of the Constitution. To this end, National and County Government Intergovernmental Coordinating Summit have been undergoing as a forum for intergovernmental relation and dispute resolution mutatis mutandis. ${ }^{17}$ The Summit is the apex body that is expected to ensure smooth operations of the different levels of government in Kenya. It comprises the President (Deputy President at the absence of President) and the forty seven County governors in which one county has at least one representative and it promotes cohesion, unity and matters of national interest. The equal representation of all Counties and National government can potentially play a vital role in ensuring that there is no systematic partiality either favoring the National government or the Counties. The day to day operations of the Summit will be facilitated by an Intergovernmental Technical Committee (IGTC) of not more than a Chair, eight members competitively recruited and appointed by the Summit and the Principal Secretary of State department, who is responsible for matters relating to devolution. ${ }^{18}$

The Act provides for both Alternative Dispute Resolution and formal mechanisms for resolving the disputes. Section 33(1) of the Act notes that "before formally declaring the existence of a dispute, parties to a dispute shall, in good faith, make every reasonable effort to take all necessary steps to amicably resolve the matter by initiating direct negotiations with each other or through an intermediary". Moreover, Section 31 of the Act notes that the national and county governments shall take all reasonable measures to

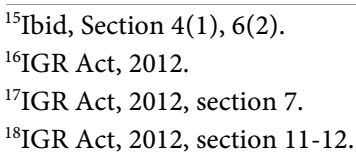


1) Resolve disputes amicably, and

2) apply and exhaust the mechanisms for alternative dispute resolution provided under this Act or any other legislation before resorting to judicial proceedings as contemplated by section 189(3) and (4) of the Constitution.

It is only if this fails that a party to a dispute may formally declare a dispute by referring the matter to the Summit established under the IGR Act of 2012. Once the dispute is submitted, within twenty-one days of the formal declaration of a dispute, to the Summit that has been established under the Act shall convene a meeting inviting the parties or their designated representatives, to determine the nature of the dispute, including the precise issues in dispute, any material issues which are not in dispute and identify the mechanisms or procedures, other than judicial proceedings, that are available to the parties to assist in settling their dispute. The Act further provides procedures after formal declaration of a dispute, including judicial proceedings. As far as the formal one is concerned, section 35 of the Act notes that where all efforts of resolving a dispute under this Act fail, a party to the dispute may submit the matter for arbitration or institute judicial proceedings. ${ }^{19}$

\section{Intergovernmental Relation in Ethiopian Federacy}

In Ethiopia, formal federal state structure has been introduced with the coming into effect of the 1995 FDRE Constitution. The Constitution proclaims in its very first article that the Constitution establishes a Federal and Democratic State structure. ${ }^{20}$ In stark departure from its predecessors, which were characterized by the unitary and centralized form of governments, this Constitution establishes a federal form of government (Adem, 2013). Nine regional states and two City Administrations have been formed. ${ }^{21}$ It also allocates legislative, executive and judicial power between federal and regional governments. The Constitution further declares that both federal and regional state shall respect the power of one another. And the Federal Government may, whenever necessary, delegate to the states power and functions granted to it as per the pertinent rule of art 51 of the Constitution. ${ }^{22}$ This provision is an indicative, at least in theory, of the dual nature of the Ethiopian federation (Regassa, 2010). Though the federal government and the regional states are vested with different power distinctly as it has been delineated under the Constitution; they are interdependent in a wide range of matters (Tewfik, 2010). Firstly, the preamble of the Constitution aims for the establishment of a common political community founded on the rule of law and capable of ensuring a lasting peace, guaranteeing a democratic order, and advancing economic and social development which demand full cooperation be-

\footnotetext{
${ }^{19}$ Section 165 (3) (C) (iii) of the Kenyan Constitution in this regard provides that High Court shall have original jurisdiction on "any matter relating to constitutional powers of State organs in respect of county governments and any matter relating to the constitutional relationship between the levels of government" which is finally appealable to court of appeal.

${ }^{20}$ Supra note 1 , art 1 .

${ }^{21}$ Ibid, art 47 and art 49, Dire Dawa is the latter development.

${ }^{22}$ Ibid , art 46, 47, 49, 50(1), (2) 50(8 \& 9).
} 
tween federal and regional states, on the other hand, and among regional states on the other. ${ }^{23}$ Other constitutional duty that calls for continuous interaction between federal and regional states is the matter relating to the respect and enforcement of fundamental rights and freedoms. In relation to this, the Constitution imposes the responsibility and duty to respect and enforce constitutional provisions of fundamental rights and freedoms on all Federal and State legislative, executive and judicial organs at all levels on equal footing. ${ }^{24}$ Economic, social and development policy matters also demand continuous and strong interrelation between federal and regional states towards achievement of the constitutional promise. In economic, social and development matters, the federal government is authorized to formulate and implement the overall policies and strategies of the country while the jurisdiction of the regional states is limited to specific policies and strategies. ${ }^{25}$ While the federal government is responsible to enact laws for the utilization and conservation of land and other natural resources, regional states are responsible to administer land and other natural resources in accordance with Federal laws. Moreover, federal government shall establish and implement national standards and basic policy criteria for public health, education, science and technology as well as for the protection and preservation of cultural and historical legacies. It shall also regulate inter-state and foreign commerce. ${ }^{26}$ In addition, the Federal Government may grant to States emergency, rehabilitation and development assistance and loans, due care being taken that such assistance and loans do not hinder the proportionate development of States. In such happenstance, the Federal Government shall have the power to audit and inspect the proper utilization of subsidies it grants to the States. ${ }^{27}$ While both federal and state governments have exclusive powers in principle, the Federal Government may, when necessary, delegate to the States power and functions granted to it by Article 51 of this Constitution. In such a case, unless otherwise agreed upon, the financial expenditures required for the carrying out of any delegated function by a State that should be borne by the delegating party. ${ }^{28}$ In relation to judicial power, the judicial authority of the federal high court and first-instance courts is delegated to the state supreme and high courts respectively. ${ }^{29}$

Another important area, which requires an effective intergovernmental relation, is joint taxation power. In joint taxation power, both the Federal Government and States shall jointly levy and collect profit, sales, excise and personal income taxes on enterprises they jointly establish. They shall jointly levy and collect taxes on the profits of companies and on dividends due to shareholders. ${ }^{23}$ Ibid, see Preamble of the Constitution para 1.

${ }^{24}$ Ibid, art 13 (1) of the Constitution provides that "All Federal and State legislative, executive and judicial organs at all levels shall have the responsibility and duty to respect and enforce the provisions of this Chapter."

${ }^{25} \mathrm{Ibid}$, art 51(2) and 52(1)(C).

${ }^{26} \mathrm{Ibid}$, art 51 (3) and (12).

${ }^{27}$ Ibid, art 94(2).

${ }^{28}$ Ibid, art 94(1).

${ }^{29}$ Ibid, art 78(2). 
They shall jointly levy and collect taxes on incomes derived from large-scale mining and all petroleum and gas operations, and royalties on such operations. ${ }^{30}$ In exercising taxation power, they shall ensure that the tax does not adversely affect their relationship. Moreover, neither states nor the federal government shall levy and collect taxes on each other's property unless it is a profit-making enterprise. ${ }^{31}$ Finally, both the federal government and states shall share revenue by taking the federal arrangement into account. ${ }^{32}$ The forgoing discussion reveals the necessity of interdependence of the federal and regional governments in one way or another in the due course of making federalism workable. However, despite the major concurrent constitutional responsibility of the federal and regional states to preserve constitutional order throughout the federation, the FDRE Constitution contains no explicit reference to intergovernmental cooperation and it does not expressly state the obligations of the respective levels of government in maintaining the constitutional order (Afesha, 2015). Unlike the Constitution of Nigeria, South Africa and Kenya, the Ethiopian Constitution has neither envisaged the system of vertical intergovernmental relations (IGR) nor given a clue as to the guiding principles and the institution in charge with such authority. In spite of the wide range of affairs which require continuous synergy among the federal and regional governments; it is highly preventive to allocate enough provisions in the Constitution to regulate IGR. (Solomon Negussie, 2008 cited in Nigussie Afesha, 2015) Even the existing rudimentary provisions remain largely unimplemented. (Ibid) The Constitution seems to have loopholes in terms of offering sufficient provisions for intergovernmental cooperation (Afesha, 2015). There are, thus, the legislative gap in intergovernmental relations and institutions with an explicit aim of facilitating the cooperation. (Ibid) It is to mean that FDRE Constitution fails to give a clue as to the mode of relationship between the federal and regional states and how will they work together especially in areas of shared power that demand a mandatory interaction between the two levels of government (Bekalu, 2015). Though the extent and degree of cooperation during their interaction may vary across the federations, intergovernmental relation always exists in any federation. By and large, the need for effective and genuine institutional setup of IGR, which is superseded with a legal framework to govern its purpose and function, is obviously essential. (Ibid) This is because of the fact that formal mechanisms of intergovernmental relations are important means of cooperation and solidarity between the center and constituent units. (Ibid)

In order to fill this constitutional gap, HPR has prepared a policy framework to regulate intergovernmental relation recently. ${ }^{33}$ As per the policy framework, federal-regional intergovernmental relations are: - federal legislative to state leg${ }^{30}$ Ibid, art 98.

${ }^{31}$ Ibid, art 100

${ }^{32}$ Ibid, art 95.

${ }^{33}$ The explanatory notes on the draft of the Federal Democratic Republic of Ethiopia's Intergovernmental Relation law May 2019 and the Policy frameworks; the explanatory of the Federal Democratic Republic of Ethiopia's Intergovernmental Relation July 2017 (Addis Ababa). 
islative, federal executive to state executive, federal judicial to state judicial, sector based relation, House of Federation to regional state council, and intra-regional state relation. ${ }^{34}$

\section{Inter-Federal-Regional Conflict Resolution Mechanisms in Ethiopian Federacy: A Comparative Appraisal on the Legal and Institutional Frameworks}

The FDRE Constitution is aimed at building one common political and economic community based on the rule of law and capable of guaranteeing sustainable peace, democracy and socio-economic development; saving therein the regular interaction between federal and regional states. However, it has failed to draw the mode of relationship between the federal and regional states and how they should work together. There is a clear loophole regarding how intergovernmental relation between the center and regional states is regulated. Nevertheless, the Constitution does not contain any way out in this regard. In the absence of legal framework and institutionalized mechanism that regulates intergovernmental relation; it can hardly possible to manage it. Equally important question is also that how can a dispute that might occur between Federal-State be resolved? What are the legal and institutional mechanisms in place to resolve federal-regional inter-governmental dispute in Ethiopia? In striking contrast to the Constitutions of Nigeria, South Africa and Kenya, the FDRE Constitution is silent about an organ which can entertain disputes between the federal government and any of the regional state while it authorizes House of Federation to settle any dispute that may occur among the Nations, Nationalities and Peoples horizontally. Some scholars claim that the HoF might seem to be a competent institution to mediate and arbitrate constitutional disputes between the federal government and regional states. So as the FDRE Constitution has aimed at building one common political and economic community; HoF is supposed to be the appropriate organ in terms of ensuring the objective of creating one economic and political community within the federation, the mandate and power of resolving such type of conflicts and misunderstandings should obviously be under the authority of this organ. Looking to the rationale of its existence, thus, the $\mathrm{HoF}$ is a competent institution to mediate and arbitrate non-constitutional disputes between the federal government and regional states. It can also be argued that the power to decide on "all constitutional disputes" as explicated under art 83(1) of the Constitution shall be broadly interpreted to include the power to resolve federal-regional intergovernmental disputes. This kind of arguments stem from the assumption that federal-regional intergovernmental resolution is inherent power of the organ with constitutional review power. They also subscribe article 23 of Proclamation No. 251/2001 that has been adopted for the consolidation of the power and responsibilities of the House of federation. This position is, finally, reinforced by policy framework. As per the policy framework

${ }^{34}$ Ibid, See the Policy frameworks, p. 16-23. 
when the concerned regional and federal governments failed to reach at an agreement by following procedures provided for in the policy framework, they shall, finally, submit their dispute to the HoF, which is legally empowered to resolcve such a dispute.

However, though this line of argument seems to be tenable as the thing stands now, the writers of this article don't agree with such assertion for some pragmatic reasons. For one thing, HoF is not constitutionally vested with the power to facilitate intergovernmental relation in general and resolve federal-regional dispute in particular. Rather, it is vested with the power, inter alia, interpreting the Constitution; deciding in accordance with the Constitution on issues relating to the rights of Nations, Nationalities, and Peoples in relation to self-determination including the right to secession, promoting the equality of the peoples of Ethiopia as enshrined in the Constitution and consolidating their unity based on their mutual consent; striving to find solutions to disputes or misunderstandings that may arise between nation, nationality and peoples; determining the division of revenues derived from joint Federal and State tax sources, and the subsidies that the federal government may provide to the States; deciding all constitutional disputes as well as the constitutionality of federal or state laws; determining the undesignated power of taxation and authorizing federal intervention. As noted above, the power of adjudicating all constitutional disputes may include umpiring federal-regional inter-governmental disputes based on the assumption that constitutional umpiring organ would naturally assume the power to umpire federal-regional disputes. This is self-evident fact when we look into the trends of Nigeria, Kenya, and South Africa where Supreme Court, High Court and Constitutional Court have the power to umpire federal-regional disputes respectively. The consequence is that, had the Constitution intended to give the power to resolve federal-regional intergovernmental disputes, it would have clearly provided in black and white. Otherwise, it would be unconstitutional to give the power of disposing such dispute to the HoF as an appropriate forum without any platform to this end. For example, the Constitution empowers HoF to resolve inter-state disputes as the pertinent rule of art 48 and 62(6) in a straight up language while it is quite silent concerning federal-regional dispute resolution mechanism. The other point is that an organ with the power to facilitate intergovernmental relation naturally assumes the power to resolve any disputes arising out of such relations. For example, the National and county Government Coordinating Summit whose power is to facilitate intergovernmental relation between National and County assumes the power to handle any disputes between National Government and County. Coming to Ethiopian federacy, neither the Constitution nor subsidiary legislation empower the HoF federation to facilitate the intergovernmental relation. Therefore, how can HoF assume the power which is not constitutionally vested on it? As such, any venture to empower the $\mathrm{HoF}$ to adjudge inter-federal-regional disputes would be unconstitutional as per art 9(1) of the Constitution for they extend the power of HoF beyond what is provided in the Constitution.. In fact, in federated states, the use of the federal 
second chamber is mainly to serve as a forum of representing the states. In this model, the federal second chamber becomes an important instrument in articulating states' rights or interests. The case of Ethiopia is, however, different from many federations concerning the purpose of the upper house (HoF) which is complete departure from prior established and known practices.

Another point is that the issues of intergovernmental dispute should be handled by an independent and impartial organ that is supposed to represent the interests of both level of governments with no bias and prejudice. For example, in Kenya, National and County IGR forum Summit is comprised of the President (Deputy President in the absence of President) and forty seven County governors in which to the least one county has one representative in the summit. In the same tune, in Nigeria for example, the fact that both the federal and state governments are involved in appointment of members of the Supreme Court could enhance the neutrality and legitimacy of the Court to adjudicate federal-state dispute. However, Ethiopia none of the regional state claims to be represented in HoF in strict sense of the term. Rather, the nation, nationalities, and peoples of Ethiopia are represented without having direct contact with federal government. This is particularly true in most diversified regional states like SNNPR, Gambella and B/Gumuz where more than one ethnic group resides. None of the regional states in Ethiopia claimed to have been represented in HoF in its statehood capacity rather the representation given for the nation, nationalities and peoples found in these regions. Though it is not necessarily true, intergovernmental disputes most likely arise between federal and regional governments in which HoF has legally remote access. Moreover, HoF is more or less akin to federal government for its members are elected by state Council, which is politically accountable to the federal government in one way or another. In this instance, thus, it could hardly possible to expect full independency and impartiality from the HoF.

Ministry of Peace has, recently, got an explicit recognition of being a center for intergovernmental relation with the power, for instance, of serving as a focal point in creating good federal-regional relationship and cooperation based on mutual understanding and partnership thereby strengthen the federal system. Setting aside the constitutionality of the power of Ministry of Peace vis-à-vis the power of HoF, Ministry of Peace is supposed to have the legitimate power to resolve federal-intergovernmental relation conflict as it is mandated to serve as a focal point in creating good federal-regional relationship and cooperation based on mutual understanding and partnership towards strengthening the federal system. Even if it is acceptable that Ministry of Peace (MoP), which has the power to facilitate IGR, has the power to adjucate inter-federal-regional disputes based on the assumption that the organ having the power to coordinate intergovernmental relation will assume the power to resolve any dispute arising out of such relation; a close examination of the power of Ministry of Peace by itself may not produce the conclusion that it has the power to handle inter-federal-regional disputes. Firstly, the very power of the $\mathrm{MoP}$ is not facilitating intergovernmental 
relation in strict sense of the term for its power is mainly empowering and supporting regional states deserving special support, following and monitoring the implementation of federal policies and decisions. Here, the MoP serves on behalf of the federal government instead of serving as a forum between federal and regional government. This is due to the fact that $\mathrm{MoP}$ is an executive organ of federal government. Therefore, the problem of impartiality and independency aforementioned against $\mathrm{HoF}$ would reoccur again. A cursory looking into the composition and function of MoP itself demonstrates that MoP is not in a position to deal with the issues of federal-regional dispute resolution independently and impartially so that it is an executive organ of federal government. Given this fact, most of its power and functions are monitoring and following the implementation of federal government's decisions and policies. Again even if we admit that the MoP has the power to settle federal-regional disputes, the establishment proclamation of MoP has neither explicitly provided basic guiding principle as to how to resolve federal-states conflict nor referred the matter to be determined by either way.

Another triggering issue here is that the settling of Federal-regional dispute is given to HoF by another proclamation surprisingly. This by itself causes another problem of determining which law prevails over the other. Since both of them are proclamations with the same status of different time of adoption, based on the canon of interpretation which says latter prevail over the former, the MoP establishment proclamation No. 1097/2018 will take precedence over the former and leading to the conclusion that $\mathrm{MoP}$ has the power to settle federal-regional dispute. However, in the above discussion, we apparently established that the MoP in any way has no power to adjudicate federal-regional intergovernmental disputes. The conclusion is that neither the HoF nor the MoP can be a legitimate organ to entertain federal-regional intergovernmental disputes.

There is an argument which claims that since federal laws prevail over regional laws. So, there might not be issues of intergovernmental conflict for the regional laws that contradict with the federal laws so that they are declared null and void. The Constitution does provide for the supremacy of federal laws. Besides, it is the federal Court establishment proclamation under its article 6(2) that extends supremacy of federal laws over the regional laws by declaring "regional laws shall not be applicable where they are inconsistent with 'Federal laws." ${ }^{35}$ The supremacy of federal law, however, should have been proclaimed in the Constitution and not in the subsidiary laws. Interestingly, this proclamation limits the application of federal supremacy in judicial proceeding. After all, what worth mentioning here is that federal- regional intergovernmental conflict may go beyond the contradiction between federal and regional law, it refers to every corner of their interactions. Generally, the comparison among the three systems indicates that there has been the practical need to set legal and institutional framework federal-regional intergovernmental dispute resolution mechanisms ${ }^{35}$ Proclamation 25/1996, Ethiopian Federal Courts Establishment Proclamation, $2^{\text {nd }}$ year, No. 13, Addis Ababa, 15 $5^{\text {th }}$ February 1996. 
as the matter of necessity in line with an inevitable reality as to their bilateral interactions under the element of surprise pragmatically. Therefore, Ethiopian system should have had an appropriate legal and institutional framework for the federal-regional intergovernmental dispute resolution mechanisms due to the pragmatic demands and factual realities on the ground in the federated state.

\section{Concluding Remarks}

In the due course of devising institutionalism for power division, federalism gives rise for an intergovernmental relation, which could lead to dispute as a norm rather than an exception. This, in turn, makes an institutionalized mechanism to settle intergovernmental dispute as a matter of necessity most importantly. Despite the importance of institutionalized intergovernmental dispute resolution mechanisms in federal state structure, there is no federal-regional intergovernmental dispute resolution mechanism in Ethiopian federation. In other words, in striking contrast to the Constitution of Nigeria, South Africa, and Kenya, the Constitution of Ethiopia contains no explicit provision in relation to how federal-regional dispute could be regulated while it empowers House Federation to settle inter-state dispute when the concerned states fail to reach at their own consensual agreement. Comparatively speaking to Ethiopian federacy, intergovernmental dispute settlement system in Nigeria, South Africa, and Kenya is strong enough in promoting unity and subtle integration. However, it is interesting to note that there is divergence among federation as to the institutional choice owing to their politico-legal setup. For example, while Nigeria and Kenya empower ordinary court to settle intergovernmental dispute, South Africa opted for Constitutional Court. Yet, both Nigeria and South Africa are centralized as intergovernmental dispute resolution power is given originally and exclusively to high court and constitutional court respectively. Kenya on its part has adopted diffused approach since intergovernmental dispute resolution vests first instance jurisdiction on high court, saving therein appellate jurisdiction for the court of appeal finally. However, the FDRE Constitution is different from the above trends by empowering House of Federation to arbitrate inter-regional disputes as the sole option, on the one hand, and not regulating federal-regional intergovernmental dispute settlement mechanism, on the other. Unlike others, moreover, inter-regional intergovernmental dispute resolution is vested on political organ in Ethiopia, which is neither ordinary court like in case of Nigeria and Kenya nor Constitutional Court as in case of South Africa. As far as the resemblance is concerned, like Nigeria and South Africa, Ethiopia is centralized an inter-regional dispute settlement body. Besides, for federal-regional intergovernmental dispute settling mechanism, Ethiopia has left open with no reason though the interrelation of governments at different level is factual. So does the possibility of dispute. Furthermore, inter-federal-regional intergovernmental dispute resolution mechanism has attracted less academic attention. Finally, the authors recommend constitutional amendment as one possible solution so as to 
incorporate provisions dealing with federal-regional intergovernmental dispute resolution and establishing independent, strong, and impartial organ which is a genuine representative of both federal and regional governments.

It has a high potential to strengthen vertical and horizontal cooperation in Ethiopian Federalism. However, this potential remains untapped. The significance of the Intergovernmental dispute settlement mechanism as a platform for inter-governmental coordination and its potential for pro-activism in fostering collaborative federalism has increased in the context of coalition era. Finally, it is of significance importance in blowing self-rule/administration and tolerance, in wide spreading some democratic virtues and principles, more often than not. Therefore, it is the tool for social, economic and political lethargy in the multination federalism through illuminating the brightening lesson of common hope and integrity to staying together and dismantling any enrooting threat of disintegration with its vices and evils potentially.

\section{Acknowledgements}

We would like to extend our deepest indebtedness to the editorial staff of the BLR and the anonymous reviewers for their important remarks and constructive comments.

\section{Conflicts of Interest}

The authors declare no conflicts of interest regarding the publication of this paper.

\section{References}

Adem, K. A. (2013). Umpiring Federalism in Africa: Institutional Mosaic and Innovations. African Studies Quarterly, 13, 53-79.

Afesha, N. (2015). The Federal-State Intergovernmental Relationship in Ethiopia: Institutional Framework and Its Implication on State Autonomy. Mizan Law Review, 9, 341-368. https://doi.org/10.4314/mlr.v9i2.4

Akai, K. P. (2017). Re-Visiting the Structure Foundation of Nigeria Federalism. International Journal of Advanced Research in Public Policy, Social Development and Enterprises, 2, 131-147.

Amah, E. I. (2016). Federalism, Democracy and Constitutionalism: The Nigerian Experience. Journal of Law, Policy and Globalization, 53, 1-14. https://iiste.org/journals/index.php/JLPG/article/view/33259/34157

Amah, E. I. (2017). Federalism, Nigerian Federal Constitution and the Practice of Federalism: An Appraisal. Beijing Law Review, 8, 287-310. https://doi.org/10.4236/blr.2017.83017

Assefa, F. (2009). The System of Intergovernmental Relations (IGR) in Ethiopia: In Search of Institutions and Guidelines. Journal of Ethiopian Law, 23, 96-131.

Bekalu, M. (2015). The Move towards Developmental State in FDRE: The Role of Intergovernmental Relation (IGR) for Its Implementation Preserving the Autonomy of Regional States. LLM Thesis, Addis Ababa: Addis Ababa University.

Bello, M. L. (2014). Intergovernmental Relations in Nigeria: An Assessment of Its Practice 
at the Local Government Level. Journal of Poverty, Investment and Development, 4, 66-76.

Harun, I. (2016). The Tortuous Journey of Federalism in Somalia: Current and Future Hopes (Vol. 3, pp. 133-163). Addis Ababa: Central for Federalism and Governance Studies, Addis Ababa University.

Isioma, U. I. (2010). Strengthening Intergovernmental Relations for Improved Service Delivery in South Africa: Issues for Consideration. Journal of US-China Public Administration, 7, 51-57.

Kenna, D. (2014). The Impact of Federal-States Intergovernmental Relations on Regional States Autonomy in Ethiopia. LLM Thesis, Addis Ababa: Addis Ababa University.

Layman, T. (2003). Intergovernmental Relations and Service Delivery in South Africa: A Ten-Year Review. https://sarpn.org

Mitullah, W. V. (2012). Intergovernmental Relations Act 2012: Reflection and Proposals on Principles, Opportunities and Gaps. FES Kenya Occasional Paper No. 6. https://www.google.com/search

Opeskin, B. R. (1999). Mechanism for Intergovernmental Relations. In International Conference on Federalism Mont-Tremblant. Ottawa: Forum for Federation. http://www.forumfed.org

Regassa, T. (2004). State Constitutions in Federal Ethiopia: A Preliminary Observation. https://www.researchgate.net/publication/2581552597_State_constitutions_in_federal_ Ethiopia

Regassa, T. (2010). Comparative Relevance of the Ethiopian Federal System to Other African Polities of the Horn. Bahir Dar University Journal of Law, 1, 5-48.

Tella, C. M., Doho, A. W., \& Bapeto, A. (2014). The Evolution, Development and Practice of Federalism in Nigeria. Public Policy and Administration Review, 2, 51-66. https://doi.org/10.15640/ppar.v2n4a4

Tewfik, H. (2010). Transition to Federalism: The Ethiopian Experience. Ottawa: Forum of Federations. http://www.forumfed.org

Van der Waldt, G., \& du Toit, D. F. P (1997). Managing for Excellence in the Public Sector. Kenwyn: Juta.

Wondirad, A. (2014). An Overview of the Ethiopian Legal System. CLJP/JDCP, 20, 174-194. 